\title{
Critical Standpoint: Leaders of Color Advancing Racial Equality in Predominantly White Organizations
}

\author{
Brad R. Fulton \\ Indiana University \\ Michelle Oyakawa \\ Ohio State University \\ Richard L. Wood \\ University of New Mexico
}

Acknowledgements:

The authors contributed equally to this article. We gratefully acknowledge primary funding for the National Study of Community Organizing Organizations provided by Interfaith Funders, along with secondary grants from the Hearst Foundation, Society for the Scientific Study of Religion, William K. Kellogg Foundation, Religious Research Association, Center for the Study of Philanthropy and Voluntarism, and Duke University's Graduate School and Department of Sociology. Additional funding was provided by the Lilly Endowment via the Louisville Institute. The qualitative data collection was supported by a Silverman Research Support Grant from the Ohio State Sociology Department. Thank you to Korie Edwards and anonymous reviewers for their helpful feedback on earlier drafts of this article and Elisabeth Andrews for her editorial assistance. An earlier version of this article received the Felice Davidson Perlmutter Best Paper Award from Theories, Interests, and Boundaries Section of the Association for Research on Nonprofit and Voluntary Associations. 


\title{
Critical Standpoint: \\ Leaders of Color Advancing Racial Equality in Predominantly White Organizations
}

\begin{abstract}
Organizations are often core sites for the production and perpetuation of social inequality. Although the U.S. is becoming more racially diverse, organizational elites remain disproportionately white, and this mismatch contributes to increasing racial inequality. This article examines whether and how leaders of color within predominantly white organizations can help their organizations address racial inequality. Our analysis uses data from a national study of politically oriented civic organizations and ethnographic fieldwork within one predominantly white organization. We draw on institutional work research, the outsider-within concept, and insights from critical whiteness theory to explain how leaders of color can use their position and "critical standpoint" to help guide their organization toward advancing racial equality. The qualitative analysis shows how such leaders, when empowered, help their organization address race internally by 1) providing alternatives to white-dominated perspectives, 2) developing tools to educate white members about racial inequality, and 3) identifying and addressing barriers to becoming a more racially diverse organization. The qualitative analysis also shows how leaders of color help their organization address race externally by 1) sharing personal narratives about living in a white-dominated society and 2) brokering collaborations with organizations led by people of color. This research has implications for organizations seeking to promote social equality: Organizational leaders from marginalized status groups can help their organizations address social inequality, if those leaders possess a critical standpoint and sufficient organizational authority.
\end{abstract}




\section{Critical Standpoint: \\ Leaders of Color Advancing Racial Equality in Predominantly White Organizations}

A critical fact of U.S. society is the mismatch between its increasing racial and ethnic diversity and the continued predominance of white organizational elites. ${ }^{1}$ That mismatch, coupled with disproportionate white control of wealth and income (Shapiro, Meschede, and Sullivan, 2010), partisan gerrymandering of districts (Hebert and Jenkins, 2010), and the manipulation of voting laws (Hajnal, Lajevardi, and Nielson, 2017) results in disproportionate political influence exerted by white people. Although the U.S. will soon become a "majorityminority" society, research suggests that the organized expressions of civil society in the U.S. will continue to be predominantly white for years to come (Omi and Winant, 2014). Because organizational life structures political representation and democratic skills building (Verba, Schlozman, and Brady, 1995), this overrepresentation of white people among organizational elites can hinder efforts to advance racial equality. More generally, this overrepresentation can exacerbate structural racial tension in U.S. society by pitting an increasingly diverse society against white organizational elites.

Throughout U.S. history, racial and ethnic minorities have led movements for racial equality_albeit often with involvement from white allies (Morris, 1984). Given the continuing predominance of white organizational elites, many scholars argue that people of color need white allies in the contemporary struggle for racial equality (Warren, 2010). Moreover, the literature on "white anti-racism" argues on moral grounds that this struggle ought to be primarily the burden of white people (Ignatiev and Garvey, 1996). However, many white people prefer to adopt a "colorblind" posture, which often serves to mask structural racism and perpetuate racial inequality (Bonilla-Silva, 2003; DiAngelo, 2018; Foldy and Buckley, 2014). 
Given that people of color have historically led efforts to achieve racial equality, we examine whether and how leaders of color within predominantly white organizations can help their organizations do this work. Research on representative leadership suggests this can be done (Clarke, 2006; Ganz, 2009; author cite). However, empirical evidence supporting this claim is limited, and little is known about precisely how leaders of color might promote racial equality within predominantly white organizations (Ospina and Foldy, 2010). To help fill this gap, this study draws on research on "institutional work" - defined as "the purposive action of individuals and organizations aimed at creating, maintaining and disrupting institutions" (Lawrence and Suddaby, 2006:215)—and combines the "outsider-within" concept (Collins, 1986) with insights from critical whiteness theory. We argue that some people of color bring into predominantly white contexts a "critical standpoint" developed through living as a racial minority in a whitedominated society. When such people are empowered within predominantly white organizations, they can use their position and critical standpoint to promote racial equality through institutional work to challenge and change the organization's white-dominated perspectives and practices. While this article focuses on the role of leaders of color, it does not absolve white people from their responsibility to address racial inequality nor does it diminish the importance of white people empowering leaders of color in transforming such organizations.

To better understand whether and how leaders of color can help predominantly white organizations address racial inequality, this study uses a multi-method approach to examine the leadership and activities of politically oriented civic organizations that are predominantly white. The quantitative analysis indicates that having leaders of color is associated with predominantly white organizations addressing racial issues both internally and within the public sphere. The qualitative analysis shows how leaders of color can use their position and critical standpoint to help predominantly white organizations address race internally by 1) providing alternatives to 
white-dominated perspectives, 2) developing tools to educate white members about racial inequality, and 3) identifying and addressing barriers to becoming a more racially diverse organization. The qualitative analysis also shows how leaders of color help their organization address race externally by 1) sharing personal narratives about living in a white-dominated society and 2) brokering collaborations with organizations led by people of color.

These findings contribute to research on organizations and inequality by demonstrating how leaders of color can help predominantly white organizations promote racial equality. This research also has implications for organizations seeking to promote social equality more broadly (Ospina and Foldy, 2010). Our findings suggest that when members of marginalized groups are empowered within organizations (e.g., given autonomy, authority, resources, and support, and not undermined), they can use their position and critical standpoint to engage in institutional work that disrupts exclusionary dynamics and promotes greater equality.

\section{Inequality in Organizations, Institutional Work, and Leaders}

Organizations are often core sites where social inequality is produced and perpetuated (Acker, 2006). While extensive research details how organizations increase inequality (Stainback, Tomaskovic-Devey, and Skaggs, 2010), less is known about how organizations can reduce it (DiTomaso, Post, and Parks-Yancy, 2007; Zanoni et al., 2010). Particularly understudied is how racial inequality is addressed in predominantly white organizations (Wingfield and Alston, 2014).

Organizational efforts to address racial inequality face institutional pressures that work against disruptive transformation (Dimaggio and Powell, 1983; Meyer and Rowan, 1977). Early institutional approaches to understanding organizations focused on the convergence and reproduction of organizational practices, rather than on efforts to resist isomorphic pressures (Oliver, 1991) or purposively change organizational assumptions. A growing literature on institutional work has been filling this gap by highlighting how individual and collective actors 
shape institutions, including via intentional efforts to disrupt them (Lawrence, Leca, and Zilber, 2013). Most studies on disruptive institutional work, however, have focused on field- and organization-level conditions that enable transformation, largely neglecting individual-level enabling conditions (McAdam and Scott, 2012). As a result, understanding of how individual actors can disrupt institutions is limited (Battilana and D'aunno, 2009) and the role of leaders in organizational change is under-theorized (Brimhall, 2019; Kraatz, 2009).

This study addresses these gaps by focusing on organizational leaders engaged in disruptive institutional work. By analyzing how leaders of color address racial inequality, this study links critical and institutional perspectives on organizational change. We posit that leaders' positions within racialized power structures can influence their ability to engage in institutional work to promote racial equality. Furthermore, we contend that a key condition for advancing racial equality within an organization is having leaders of color and empowering them to do institutional work.

Prior research on race in organizations indicates that white people and people of color often have different preferences for approaching racial issues (Bonilla-Silva, 2003; McCorkel and Rodriquez, 2009). Because white people tend to prefer colorblind approaches, these approaches have become institutionalized in many white-dominant organizations (Foldy and Buckley, 2014). As a result, predominantly white organizations, even those oriented toward social equality, can be reluctant to directly confront racial issues (Slocum, 2006). People of color in such organizations often express frustration with the superficial and ill-informed ways white leaders tend to handle racial issues, asserting that white people's perspectives, emotions, and experiences remain at the center of organizational culture (Perry, 2012; Srivastava, 2006). Also, the mere presence of people of color in predominantly white organizations does not necessarily lead to greater equality (Harris, 2012; Hughey, 2010). Even in organizations with moderate levels of racial diversity, white perspectives and practices often dominate (Edwards, 2008; Ward, 
2008). Thus, neither incorporating people of color nor stating the goal of racial equality is sufficient means to that end.

Research shows several unique contributions that leaders from non-dominant groups in society can make to their organization. For example, African-American women executives often employ boundary-spanning communication that includes connecting their organizations to the black community (Parker, 2001). In addition, "cultural outsiders" who have a national background that differs from their team members contribute to increased team creativity (Jang, 2017). Employees who are racial minorities tend to be adept at exposing race-based contradictions in organizational discourses and practices (Zanoni et al., 2010). Consequently, this study focuses on empowered leaders of color within predominantly white organizations whose institutional work can change their organizations' approaches to racial issues (Kellogg, 2011).

Our analysis focuses on two prominent ways predominantly white organizations can advance racial equality: 1) by addressing racial inequality within the organization, such as educating members about structural racism, countering assumptions that privilege white members, and empowering racial minorities in the organization and 2) by addressing racial inequality in the public sphere, including educating the public about racial discrimination, advocating for policies that reduce segregation, and promoting initiatives that direct resources to racially marginalized neighborhoods.

\section{Critical Whiteness Theory and the Outsider-Within Concept}

To better understand how leaders of color might help predominantly white organizations promote racial equality, we draw on critical whiteness theory—-the study of whiteness within the sociology of race/ethnicity—and the outsider-within concept. Critical whiteness theory argues that white privilege looks "normal and natural" to many people (Delgado and Stefancic, 2013; Hatch, 2007). The theory asserts that most white people do not "see" the racial benefits they accrue 
(Garner, 2007; McIntosh, 1990). This blindness to white privilege impairs white people's ability to recognize racism operating within organizations and society at large (Bonilla-Silva, 2003; Staiger, 2004). Even white people who are committed to reducing racial inequality can hold colorblind perceptions of self and society that deemphasize racialized structures (McCorkel and Rodriquez, 2009). Furthermore, many white people see themselves as "cultureless" (Perry, 2001) and view people of color as having a culture that is outside the (white) norm (Frankenberg, 1993). Indeed, “when people of color are not present, often whites believe that 'race' itself is absent" (McKinney, 2005:43). These (mis)perceptions can inhibit white people's ability to recognize racialized dynamics within organizations.

A long tradition of scholarship in race/ethnicity asserts that people of color have a distinct perspective that enables them to see the workings of race-based entitlement and prejudice (Collins, 1986; DuBois, 1903; Fanon, 1967; hooks, 1998). DuBois (1903) explains that black people possess a "double consciousness" from functioning in a white dominant society: black people internalize white narratives about blackness and have firsthand experience of how racial power structures devalue their perspectives. Contemporary scholars explain that people of color often have "special knowledge of whiteness" (hooks, 1998:38), largely due to their experiences of racial marginalization in a white-dominated society. As such, racial minorities in the U.S. often experience cultural dynamics in which they are racialized as "Other" and excluded from power centers in society (Ahmed, 2004). Because of these experiences, people of color can more readily identify perspectives and practices that are racially biased (Carbado and Gulati, 2000). Although this literature is probabilistic rather than deterministic (e.g., not every person of color is aware and critical of factors contributing to racial inequality and there are white people who disavow colorblindness and critique white privilege), most research supports the claim that 
people of color are more likely than white people to recognize and critique racial inequality (Ahmed, 2004; Bonilla-Silva, 2003).

These aspects of critical whiteness theory are closely related to the outsider-within concept. Outsiders-within are members of marginalized social groups who live and work in settings controlled by dominant group members (Collins, 1986). The outsider-within concept posits that people's perceptions of a situation depend greatly on their positions within embedded social relations that are structured by power (Collins, 1997). While dominant perspectives are often presented as the only perspectives, there are multiple vantage points from which social situations can be understood (Collins, 1986). Moreover, the outsider-within concept highlights how marginalized members of society can provide valuable alternative perspectives that are often unrecognized (Bell, 2009; Jang, 2017).

Applying this concept, members of historically privileged or dominant groups are likely to see situations refracted through their privileged view, regardless of their intentions. For example, some men might be blind to the disempowering effects that traditional gender roles can have on women. In contrast, members of subordinated groups are likely to see situations through the lens of living in a society dominated by another group (Collins, 2006; DuBois, 1903; Wylie, 2013). For example, women of color in academia can offer distinct perspectives on issues of race and gender because of their status as outsiders within white- and (at times) male-dominated academic cultures (Collins, 1986). Similarly, feminist scholars argue that philosophy and science prioritize male perspectives and that a woman's standpoint can add significant insight (Harding, 2004; Hartsock, 1983; Smith, 1987). This outsider-within status enables subordinated group members to generate unique insights about that setting (Schilt, 2006) and to critique and contest social inequality (Kwon, 2015). 
The outsider-within concept need not assume that one perspective holds "the truth" in any pure sense. Rather, it contends that assessments that rely only on dominant group perspectives produce a limited view of reality that can obscure inequitable practices and undermine efforts to promote equality. For instance, research on law firms finds that male attorneys are less conscious of gender bias and inequality than female attorneys (Martin, Reynolds, and Keith, 2002). By extension, predominantly white organizations that draw only from white perspectives are likely to underestimate their racial bias (Ward, 2008). In contrast, predominantly white organizations that draw also from the perspectives of leaders of color can have a more comprehensive understanding of their organization's racial dynamics. These leaders, who are better positioned to critique their organization's white-dominated perspectives and practices, are consequently better positioned to advance institutional work that promotes racial equality.

Combining critical whiteness theory and the outsider-within concept, we argue that leaders of color can help predominantly white organizations work for racial equality by providing a "critical standpoint" - an outsider-within perspective that allows them to see and critique racialized dimensions of organizational life. This theoretical framework, along with the authors' ethnographic research presented below, leads us to explore the role of leaders of color within predominantly white organizations. Our quantitative analysis examines whether having leaders of color is associated with predominantly white organizations having an internal and external focus on race. The qualitative analysis examines how leaders of color who possess a critical standpoint help predominantly white organizations work for racial equality.

\section{Overview of Community Organizing Organizations}

To examine whether and how leaders of color can help predominantly white organizations address racial inequality, we analyze a sample of predominantly white organizations engaged in community organizing (Hart, 2001; author cite). These organizations 
are best understood as politically oriented civic organizations, as they have characteristics of both social movements and civic organizations. Similar to social movement organizations, they mobilize constituents to address issues through the public exercise of political power (Morris, 1984; Tarrow, 1994). Similar to civic organizations, their most common forms of public engagement are collective civic actions (Sampson et al., 2005). Given their social justice mission, community organizing organizations often engage in issue work associated with racial inequality, which makes them a useful case to analyze for this study. Furthermore, these organizations are important to study because if more organizations begin to address racial inequality, some will likely adopt the practices of organizations with experience working on these issues (Dimaggio and Powell, 1983).

Historically, although most of these organizations addressed issues that disproportionately affect racial minorities in the U.S., many pursued this work while avoiding discussions focused explicitly on race (Hart, 2001; author cite). While many community organizing leaders believed that such discussions would be divisive, others, mostly leaders of color, criticized "race-blind" organizing. Addressing poverty in the U.S. while neglecting the pernicious influence of racism, they argued, ignored the experience of communities of color and could not succeed (Sen, 2003). Nevertheless, the bulk of work in this field continued to address issues that disproportionately affect racial minorities without explicitly focusing on race.

Over the past decade, while some of these organizations have continued this pattern of addressing race only indirectly, others have moved to systematically incorporate an explicit focus on race into their work (author cite). This bifurcated response to race among these organizations is reflected in 2011 data from the National Study of Community Organizing Organizations (described below). Among the predominantly white organizations, over 60 percent indicated that they are addressing issues related to poverty, while less than 30 percent indicated that they are 
addressing race-related issues. Similarly, approximately one third of the predominantly white organizations regularly discuss racial differences in their planning meetings (author cite).

\section{Quantitative Data and Analysis}

To examine the association between an organization having leaders of color and its likelihood of addressing racial inequality, we analyze data from the National Study of Community Organizing Organizations (NSCOO) (author cite). Although the organizations in this study are situated in different community contexts, they share a similar structure and mission. They operate as community-based organizations that bring together individuals from their member institutions to address social, economic, and political issues that affect poor, lowincome, and middle-class sectors of U.S. society. Each organization has two types of leaders: paid community organizers and a board of directors consisting of representatives from its member institutions, which include religious congregations, nonprofit organizations, schools, unions, and other civic associations. Because the organizations tend to have a relatively flat hierarchy and a culture of empowering their leaders, the paid organizers have substantial autonomy to develop strategies and direct organizational activities. These commonalities enable our analysis to hold the organizations' form relatively constant, while allowing their social composition and organizational activities to vary.

The national study surveyed the entire field of these organizations by asking the director of each organization to complete a survey. This study achieved a response rate of 94 percent, gathering data on 178 of the 189 organizations in the country and demographic information on the 4,145 member institutions, 2,939 board members, and 506 paid organizers affiliated with these organizations (author cite). Because this article focuses on predominantly white organizations, we restrict the sample to organizations in which at least two-thirds of their active institutional members are majority-white organizations. The resulting sample contains 41 
organizations and their 803 member institutions, 631 board members, and 100 paid organizers (see Appendix A for more details).

The analysis incorporates five dependent variables related to an organization's focus on race. The first three variables are ordered categorical variables, which measure an organization's internal focus on race: 1) how often the organization explicitly discussed racial differences in its planning meetings, 2) the extent to which racial differences prolonged its planning meetings, and 3) the extent to which racial differences complicated its planning meetings. The development of the corresponding survey items was based on ethnographic observations of organizations addressing racial issues (author cite). These survey items were designed to identify an organization's level of engagement with racial issues, while limiting social desirability bias (Blanton and Jaccard, 2008). To measure an organization's external focus on race, we use the following binary variables: 4) whether the organization actively organizes people of color and 5) whether it actively addresses race-related issues.

We measure the presence of leaders of color in each organization using a binary variable indicating whether the organization has at least one organizer of color on staff and another variable indicating the proportion of people of color on the organization's board. The analysis also controls for the age of the organization; the gender, age, and educational level of the organization's director; the gender, age, education level, and religious composition of the organization's board; and the proportion of people of color in the organization's county. Table 1 displays the descriptive statistics for the variables used in the quantitative analysis.

The analysis performs ordered logistic regressions for the ordered categorical dependent variables and logistic regressions for the binary dependent variables. Each model uses maximum likelihood methods to estimate the change in the log odds of focusing on race associated with a change in the independent variable. ${ }^{2}$ Table 2 displays the results of the five multivariate analyses. 
The first three models indicate that having at least one organizer of color on staff is positively associated with the organization having an internal focus on race. Having at least one organizer of color is associated with a four-fold increase in the likelihood of an organization discussing racial differences, and with a nine-fold increase in the odds of racial differences prolonging planning meetings. However, these models do not indicate a significant relationship between the proportion of people of color on the organization's board and the organization having an internal focus on race.

The final two models indicate that having at least one organizer of color on staff is positively associated with the organization having an external focus on race. Having an organizer of color is associated with increasing the odds of organizing people of color by a factor of almost 5 , and with increasing the odds of addressing race-related issues by a factor of 19. Again, however, these models do not indicate a significant relationship between the racial makeup of the organization's board and having an external focus on race.

This analysis provides strong evidence that among predominantly white organizations, having at least one organizer of color on staff is associated with having both an internal and external focus on race. Having organizers of color within predominantly white organizations thus matters for efforts to promote racial equality. The analysis, however, fails to provide evidence that the proportion of people of color on the organization's board is associated with having an internal or external focus on race. This null finding may be driven by variance in board members' levels of involvement and power within organizations. For example, in two organizations with the same proportion of board members of color, the members' effects on activities may differ widely, depending on their level of involvement and how much power they or the board wield. In contrast, most paid organizers are deeply involved in the day-to-day work of their organizations. In summary, the analysis indicates that a predominantly white organization's likelihood of 
addressing racial issues — both internally and externally—is associated with having people of color represented among its leaders. However, this association holds only for the paid organizers, not the board members. While the quantitative analysis indicates a relationship between having leaders of color and addressing racial inequality, it cannot explain the organizational dynamics underlying this relationship; for that, we turn to the qualitative analysis.

\section{ELIJAH: A Case Study of a Predominantly White Community Organizing Organization}

To better understand the relationship between leaders of color and work for racial equality, we draw on qualitative data from an in-depth case study of one predominantly white community organizing organization located in the Midwest-ELIJAH. ${ }^{3}$ Data from the NSCOO indicate that ELIJAH has 93 institutional members, 85 percent of which are majority-white organizations, and three organizers of color on staff. The director of ELIJAH reported that they "often" discuss racial differences in their planning meetings and that racial differences "somewhat" complicate and prolong their meetings. She also indicated that ELIJAH is "very involved" in organizing people of color and "very involved" in addressing race-related issues (see Table 1 for ELIJAH's descriptive statistics). Like many other organizations in the NSCOO, ELIJAH has a relatively flat organizational structure and a culture of empowering its leaders (e.g., giving them autonomy, authority, resources, and support). Furthermore, we selected ELIJAH for close analysis not because it is "typical" of all community organizing organizations, but because it is a predominantly white organization where organizational efforts to address racial inequality are visible. While these organizational conditions likely enhanced the ability of ELIJAH's leaders of color to engage in institutional work to promote racial equality, the conditions did not eliminate the challenges and personal costs associated with expressing and acting on a critical standpoint. 
The ethnographic fieldwork within ELIJAH was conducted by the second author during the summer of 2011, simultaneous with the NSCOO data collection. ${ }^{4}$ The ethnographic data include participant observations of organizational activities and 30 semi-structured interviews, which lasted 45 to 90 minutes and focused on respondents' participation in ELIJAH and their experiences with leadership development in the organization. ${ }^{5}$ Table 3 displays the characteristics of ELIJAH's leaders who participated in the interviews. ${ }^{6}$ Although the ethnographic study was not designed specifically to reveal how leaders of color can help predominantly white organizations address racial inequality, analysis of the observational and interview data provided extensive insight into how ELIJAH's leaders of color helped their organization promote racial equality.

\section{Leaders of Color Addressing Racial Inequality Internally}

The quantitative analysis indicates that having leaders of color is associated with having an internal focus on race. This section uses qualitative data to examine mechanisms underlying this relationship. Leaders of color advanced ELIJAH's efforts to address racial inequality within their organization by 1) challenging and providing alternatives to ELIJAH's white-dominated perspectives; 2) developing and implementing tools to educate ELIJAH's white members about racial inequality; and 3) identifying and addressing barriers to becoming a more racially diverse organization.

The experiences and perspectives of ELIJAH's leaders of color differed substantially from those of ELIJAH's white leaders and members. During the period in which interviews were conducted, ELIJAH had three organizers of color on staff, the most influential of which was Ruby - a charismatic African-American woman in her early 30s whom ELIJAH hired in $2008 .^{7}$ At the time of her interview, Ruby reported directly to ELIJAH's executive director and held the 
title of "Lead Organizer," making her the most senior organizer on ELIJAH's staff. Ruby's critical standpoint was evident in her stated motivations for involvement in organizing:

"There's a silent genocide going on with the African-American community. We lead in death and destruction, you know what I mean? We lead in certain cancer rates, HIV, we go to the penitentiary system quicker than anyone else, our infant mortality rate is off the chart. So it's kind of hard to get in the world, it's easy to get yo' ass out, you know what I mean? Even if you live, it seems like you have a freakin' prolonged existence full of depression and heartache. And... as an organizer, [I am] trying to figure out what the hell to do about that.” Ruby's piercing account of the oppression experienced by African-American people reveals how her worldview is shaped by the material realities she has seen and lived in black communities. Knowing that her people lead in "death and destruction," leads to "depression and heartache" in her own life. Ruby's personal experience and knowledge underpinned the critical standpoint that she brought to bear on organizational life. During ELIJAH's meetings and events, Ruby would often speak about racism with vulnerability and great passion, sharing a perspective that many of ELIJAH's white leaders otherwise would be less likely to encounter given that most of their social networks are comprised predominantly of white people.

ELIJAH's leaders of color brought race to the forefront of their organization by challenging its white-dominated assumptions and providing alternative perspectives. When asked about her accomplishments as an organizer, Ruby's response supports the second author's ethnographic observations indicating the central role she played in increasing ELIJAH's focus on race both internally and externally:

"I think probably the number one thing I feel proud of is being a part of and in some ways being at the center of moving [ELIJAH] to be multiracial and to focus on racial justice. For the three and a half years I've been here, that's been the majority of my work.... Whether that's 
being a part of [a coalition of mostly black community leaders] or looking at our programs or our campaigns or curriculum with [an] infusion or infiltration of racial justice, calling into question a lot of things. I just feel like I've been kind of an institutional builder. I think that's my biggest accomplishment."

Throughout the process of developing ELIJAH's training curriculums (i.e. internal work) and organizing campaigns (i.e. external work), Ruby incorporated a distinct focus on race. Ruby's African-American identity and life experiences—-her critical standpoint—enabled her to see the bias in ELIJAH's perspectives and practices. Furthermore, Ruby's influential position within ELIJAH gave her the authority to call into question her white colleagues' assumptions and challenge them to consider alternative perspectives.

The dynamic that Ruby described in her interview was also apparent in the observation data. When ELIJAH's leaders evaluated its training sessions, they often asked whether race had come up in the session. During one evaluation, Ruby suggested that ELIJAH could be more effective at addressing race if it incorporated race into the structure of the training. She provided innovative ideas to accomplish this, for example proposing that the trainers could "pit AfricanAmericans against whites" or "throw blacks out of the room" as provocative ways to prompt discussion about racialized power dynamics. Although some white leaders had emphasized the importance of noticing and discussing racial dynamics that emerge, Ruby was the first person to suggest that ELIJAH explicitly incorporate race and engage in provocative activities that might overcome participants' reluctance to recognize and discuss white privilege. She called into question how ELIJAH addresses race as an organization and advocated for an explicit focus on race informed by an understanding of racial hierarchy and power differentials. 
Ruby's suggestions reflected her sense that many of ELIJAH's white members lacked awareness of racial issues, which inhibited the organization's ability to practice racial equity internally. In response to this problem, ELIJAH's leaders created tools to help its white members see white privilege and understand structural racism. Ruby played a key role in developing and implementing those tools. In particular, she developed a training module that explained individual, institutional, and structural racism. Ruby trained ELIJAH's paid organizers, who then used this knowledge in their organizing work. In doing so, she provided an alternative perspective on the dynamics of a white-dominated organization and society, and challenged participants to adopt this perspective. Ruby used her position to ensure that ELIJAH's leadership development process explicitly acknowledged racism and involved all participants in learning about rather than eliding racism.

In another effort to address the white members' limited awareness of white privilege, a multiracial team of ELIJAH's paid organizers and volunteer leaders trained organizational participants to craft and share personalized "opportunity stories." ELIJAH used this tool to help its white leaders recognize and articulate the opportunities they had been given that may not have been offered to people of color. ELIJAH introduced this tool at a training session where Brynn (ELIJAH's white executive director) and Ruby each shared their opportunity stories, emphasizing where their race had played a role in opening or closing doors. This exercise required both speakers to inhabit a critical standpoint and view their lives through a lens of racialized mechanisms of advantage and disadvantage. Most of the trainees were white people who lived in predominantly white settings, largely disconnected from the experiences of people of color. In telling her story, Ruby exposed them to a viewpoint and a set of experiences they otherwise might not have encountered. Furthermore, having Ruby tell her story alongside a white leader provided a contrast that underscored the role of race in structuring people's lives and opportunities. 
A third component of ELIJAH's efforts to address race internally involved identifying and addressing barriers to becoming a more racially diverse organization. Hope is an AfricanAmerican woman who had multiple leadership roles in ELIJAH. She illustrated her critical standpoint when expressing concerns about ELIJAH's outreach toward people of color:

"I don't know that we do as good of a job as we can thinking about how we bring people of color into this work... There are fundamental obstacles in the lives of people of color that are going to be very different than addressing someone who's white. Part of what stands in the way of [ELIJAH involving people of color] is... the people making decisions about where we're going aren't people of color... I don't know that [race] is necessarily on the radar of [ELIJAH's white leaders]...."

Hope recognized that because most of ELIJAH's members were white, its trainings and meetings were tailored to white participants. For example, the "opportunity stories" exercise was designed primarily to educate white people. She noted that most people of color do not need to be educated about racial inequality; they often already have a critical standpoint about racial inequality because they "live in it every single day." Hope understood that in order to become more diverse, ELIJAH had to both develop its white members' critical consciousness and effectively engage and empower people of color. Furthermore, as a top leader in the organization, Hope was well positioned to recognize that ELIJAH's white leaders were not always aware of the need to prioritize race. With these insights, Hope was able to help ELIJAH identify where its organizational culture inhibited people of color from becoming involved.

In addition to identifying cultural barriers to participation, ELIJAH's leaders of color developed strategies to help address those barriers. Another leader of color, Diana, played a role in helping ELIJAH address barriers to becoming more racially diverse. A Mexican-American woman in her 50s, Diana was formerly a paid organizer with ELIJAH, and was a board member 
at the time of her interview. When describing her experience as an organizer with ELIJAH, Diana shared how she translated ELIJAH's organizing methodology for the Latinx community: "Among all the organizers back then, I was the only person of color. And the only one bicultural and bilingual.... I was working with a community that mostly didn't speak English, so all the documentation had to be translated into Spanish. Second, we [could not effectively] develop [Latinx] leaders in the [context of ELIJAH's] white culture.... So my [Latinx] leaders were constantly way behind. [Their] immigration status, education, and their understanding of English were issues for them."

Diana recognized how language and cultural barriers inhibited her community members from integrating into ELIJAH's leadership development programs. Moreover, because she was ELIJAH's only bicultural and bilingual organizer, she was the only paid organizer sufficiently equipped to recruit and train ELIJAH's Latinx constituents. Consequently, she translated ELIJAH's training materials from English to Spanish and developed curricula to help Latinx leaders understand approaches to political advocacy in the U.S., thereby working to address ELIJAH's challenges with recruiting and developing Latinx leaders.

Several of ELIJAH's white leaders emphasized the critical role people of color play in helping their organization bridge racial divides. Pastor Ken, a white leader involved with ELIJAH for nearly 20 years, illustrated this dynamic when he shared about his experience working in the Latinx community:

"It's important to have people of color being organizers...The only reason that I can work in the Latino community and [be effective] was [by] simply walking with and listening for years [to leaders in the Latinx community]. I needed guides. We're not going to be 
successful working cross-culturally while we're still dominated by European American leaders and congregations."

Pastor Ken's experience illustrates how people of color can serve as mentors, guides, and cultural translators to white organizers working in a multiracial context. Methods of organizing that have been developed by white organizers and implemented in white communities often need to be adapted to work effectively in a multiracial context. Although white people could do this translation work, people of color tend to be more adept at translating because they are more aware of cultural and linguistic barriers and are more likely to have experience navigating multiple cultural terrains (Giorgi, Bartunek, and King, 2017).

Leaders of color within predominantly white organizations do not necessarily nor automatically lead their organization to address racial inequality. Leaders' likelihood of engaging in this type of institutional work is in part determined by their ability, desire, and organizational context. The authors' fieldwork includes cases of otherwise-similar organizations that were not engaged in efforts to explicitly address racial inequality. In such cases, the organizations' leaders of color either did not articulate a critical standpoint within their organization or did so but were not empowered (and sometimes were explicitly disempowered) to bring that standpoint to bear via institutional work. Due to space limitations, we do not discuss these null examples here, but we did observe such examples in ELIJAH and other organizations. Rather than undermining our claim, the null examples help identify the conditions needed for leaders of color within predominantly white organizations to engage in institutional work to promote racial equality. In summary, the qualitative analysis reveals three ways leaders of color within predominantly white organizations can use their positions and critical standpoints to help their organizations address racial inequality internally. First, they can call into question white- 
dominated assumptions and provide alternative perspectives. Second, leaders of color can develop and implement tools to educate white people about racial inequality. Third, they can expose aspects of their organizations' cultures and practices that might inhibit people of color from becoming involved, and help their organization address those barriers.

\section{Leaders of Color Addressing Racial Inequality Externally}

Leaders of color can also help organizations address race externally. The quantitative analysis indicates that having leaders of color is associated with having an external focus on race. This section draws on the qualitative data to examine the mechanisms underlying this relationship. The analysis reveals that leaders of color advanced ELIJAH's efforts to address racial inequality in the public sphere by 1) publicly sharing personal narratives regarding the impact of structural racism and 2) brokering collaborations with organizations and communities of color.

To personalize the consequences of structural racism, ELIJAH's leaders of color often shared how they had been impacted by racial inequality. Part of the power of narratives in social change work lies in their capacity to make concrete how abstract social forces, such as structural racism, affect real people (Nepstad, 2001; Polletta, 2006). While leading a session at a training conference, Ruby opened with anger and pain in her voice, sharing a series of statements partly echoing the earlier quotation, "There is a silent genocide against African Americans in this country. African Americans lead in death and destruction...." She proceeded to describe how racism and racial inequality personally impacted her and caused her to question the presumed race-blindness of public institutions and policies. Ruby's personalized and emotionally intense presentation illustrated her critical standpoint and made the impact of structural racism more concrete for the white participants. The second author observed Ruby and other leaders of color share their experiences with racism in a variety of ELIJAH meetings and training workshops. By 
publicly telling their stories of struggle, Ruby and other leaders of color in ELIJAH helped white members better understand and connect emotionally with ELIJAH's racial justice work. Prior research on social movement organizations documents the importance of narrative in shaping organizational perspectives and practices (Polletta, 2006). Our analysis shows how ELIJAH's leaders of color used narrative to shape dialogue about racial inequality both within their organization and in the public sphere.

ELIJAH's leaders of color also advanced ELIJAH's external racial justice work by brokering collaborations with organizations and communities of color. These collaborations enabled ELIJAH to work closely with people adversely affected by racial inequality, which helped to widen its base and increase its political legitimacy. Ruby described her role in building such organizational relationships:

"What I do is make sure I have a continuing relationship, a blossoming one with [a predominantly African-American neighborhood association], getting to know them from their executive director all the way down to their leadership. We just had three people from [the neighborhood association] go to [our] weeklong training [conference]."

Ruby helped ELIJAH develop connections with this and other African-American organizations by building personal relationships and inviting people to participate in ELIJAH's activities.

Similarly, Diana, the Mexican-American woman introduced above, led ELIJAH's efforts to mobilize the Latinx community for immigrant rights:

"2005 and 6 was the peak of the immigration issue and I can say that I'm really proud of the job that I did in [that] 6 month period. [I was] constantly bringing many people... I did an event on immigration [in front of] two mayors and a state representative, and 300 people turned out at that event... I was able to be part of the big march that we had with 
thousands of people, organizing through ELIJAH. I was able to pull 15,000 people from different Catholic churches."

By building relationships with Latinx individuals and organizations, Diana mobilized large numbers of people around the issue of immigration. ${ }^{8}$ As described above, she also translated ELIJAH's organizing language and culture so that Latinxs could understand and participate in ELIJAH's public actions. In addition, by working through Latinx institutions Diana was able to recruit many Latinxs from Catholic congregations to participate in ELIJAH's racial justice work. Interestingly, following Diana's resignation, ELIJAH was unable to sustain its relationships with the Latinx community. Although Diana resigned because of family medical issues, her departure and ELIJAH's subsequent loss of connection to the Latinx community nonetheless underscore the critical role leaders of color can play in predominantly white organizations and the importance for such organizations to develop comprehensive processes for recruiting and retaining leaders of color (author cite).

Ruby's and Diana's respective ties to African-American and Latinx organizations and communities provided access to "mobilizing structures" (McAdam, Tarrow, and Tilly, 2001; Morris, 1984) that increased ELIJAH's mobilizing capacity for public events. Those ties also gave ELIJAH a more credible voice when working for racial equality in the public arena. For example, the "opportunity stories" described above were used not only in ELIJAH's internal training sessions, but also in public meetings. In the public settings, the stories demonstrated ELIJAH's commitment to connect its existing issue work to an analysis of structural racism. At one meeting with public officials present, a Filipina woman affiliated with ELIJAH highlighted racial disparities by telling her story of housing discrimination: 
"I realized from what mom and dad were saying that the landlord didn't really want to rent it to us because we were not white. I felt hurt and disappointed that somehow someone thought we weren't good enough and didn't deserve to have that apartment because it was in too nice a neighborhood and we weren't white."

Such stories personalized the realities of racial injustice and illustrated the connections between race and housing access, enabling ELIJAH to present an authentic and compelling case.

In summary, the analysis reveals two ways leaders of color within predominantly white organizations can use their position and critical standpoint to enhance their organization's efforts to address racial inequality in the public sphere. First, they can help mobilize a predominantly white base for involvement in racial justice issues by sharing stories about the personal impact of structural racism. Second, they can increase their organization's mobilizing capacity and credibility by brokering collaborations with organizations rooted in communities of color. Both of these activities represent ways that leaders of color can engage in intentional, practical, and purposeful action in order to help their organization address its habitual adherence to colorblind ideology. Noteworthy, however, is that under the model for organizational change analyzed here, the burden of helping predominantly white organizations advance racial equality falls significantly on people of color (those who generally have been disadvantaged by racial inequality) rather than primarily on white people (those who generally have been beneficiaries of racial inequality).

\section{Conclusion}

Although extensive research details how organizations propagate social inequality (Acker, 2006; Stainback, Tomaskovic-Devey, and Skaggs, 2010), less is known about how organizations can reduce inequality (DiTomaso, Post, and Parks-Yancy, 2007; Zanoni et al., 2010). Particularly thin is research on organizations reducing racial inequality (Cook and Glass, 
2013). Given that racial inequality is one of the most pressing and persistent issues facing U.S. society, this knowledge gap warrants greater analytical attention. Reducing racial inequality in the U.S. has been difficult, in part because of the concentration of social and political power among white organizational elites (Gillis, 2017; Ostrower, 2007) and because many organizational practices of predominantly white organizations serve to maintain racial hierarchies (Wingfield and Alston, 2014). Thus, understanding racial dynamics within predominantly white organizations remains particularly important.

Rather than assuming that predominantly white organizations always contribute to racial inequality, we explore how racial equality work can occur within such organizations. Our study draws on institutional work research and combines the outsider-within concept with insights from critical whiteness theory to provide a novel theoretical framework for analyzing organizational dynamics. We argue that some people of color possess a critical standpoint born out of living as a racial minority in a white-dominated society, which enables them to see and critique racialized dimensions of organizational life that others may miss. When such people are empowered within predominantly white organizations, they can use their position and critical standpoint to challenge and change organizational perspectives and practices that perpetuate racial inequality. This theoretical framework is not limited to research on racial inequality, and can be applied to other efforts to address social inequality in organizations.

Empirically, our analysis of survey data indicates that among predominantly white organizations, having leaders of color is associated with addressing racial issues both within the organization and in the public sphere. Our ethnographic data show how leaders of color empowered within a predominantly white organization use their position and critical standpoint to help their organization promote racial equality. The qualitative analysis also suggests that certain organizational conditions enhanced these leaders' ability to advance a racial equality 
agenda. These conditions include having a relatively flat hierarchy, a culture of empowering paid organizers, and supportive white leaders. More broadly, our findings have implications for any organization seeking to promote social equality. Under the right conditions, members of marginalized status groups who possess a critical standpoint and are sufficiently empowered can help their organization become more effective at addressing social inequality.

Predominantly white organizations, however, have been criticized for leaning too heavily on people of color to represent their racial/ethnic group and lead diversity-related initiatives (Joseph and Hirshfield, 2011; Padilla, 1994). Leaders of color in predominantly white contexts often do extra work to educate white people about racial dynamics, and this role can involve significant emotional labor (Moore et al., 2010). Importantly, such work is generally not compensated nor associated with increased prestige (Harris, 2012). This study seeks to highlight the contribution leaders of color can bring to predominantly white organizations and the need for such organizations to recognize the value these leaders provide as well as the burden they incur.

This study identifies important topics for future research. Given our findings on how leaders of color help organizations address racial inequality, additional studies could investigate these dynamics vis-à-vis other marginalized status groups. Similarly, more research is needed to understand what leads white people and members of other dominant status groups to support efforts to reduce racial and other forms of social inequality. At the organizational level, additional research could further specify the organizational conditions that enhance (or undermine) efforts of marginalized status group members to promote social equality. Given the role of organizations in propagating social inequality, more research is needed to examine how organizations can actively reduce inequality rather than simply diversifying their workforce within a context of ongoing social inequality. 


\section{References}

Acker, J. (2006). Inequality regimes: Gender, class, and race in organizations. Gender \& Society, 20(4), 441-464.

Ahmed, S. (2004). Declarations of whiteness: The non-performativity of anti-racism. Borderlands 3(2).

Battilana, J., \& D'aunno, T. (2009). Institutional work and the paradox of embedded agency. In T. Lawrence, R. Suddaby \& B. Leca (Eds.), Institutional work: Actors and agency in institutional studies of organizations (pp. 31-58). NY: Cambridge University Press.

Bell, A. (2009). 'It's way out of my league': Low-income women's experiences of medicalized infertility. Gender and Society, 23(5), 688-709.

Blanton, H., \& Jaccard, J. (2008). Unconscious racism: A concept in pursuit of a measure. Annual Review of Sociology, 34(1), 277-297.

Bonilla-Silva, E. (2003). Racism without racists. Lanham: Rowman \& Littlefield.

Brimhall, K. (2019). Inclusion and commitment as key pathways between leadership and nonprofit performance. Nonprofit Management \& Leadership.

Carbado, D., \& Gulati, M. (2000). Working identity. Cornell Law Review, 85, 1259-1308.

Clarke, M. (2006). A study of the role of 'representative' leadership in stimulating organization democracy. Leadership, 2(4), 427-450.

Collins, P. H. (1986). Learning from the outsider within: The sociological significance of black feminist thought. Social Problems, 33(6), S14-S32.

Collins, P. H. (1997). Comment on Hekman's 'Truth and method: Feminist standpoint theory revisited': Where's the power? Signs, 22(2), 375-381.

Collins, P. H. (2006). Some group matters: Intersectionality, situated standpoints, and black feminist thought. A Companion to African-American Philosophy, 12, 205-229.

Cook, A., \& Glass, C. (2013). Glass cliffs and organizational saviors: Barriers to minority leadership in work organizations? Social Problems, 60(2), 168-187.

Delgado, R., \& Stefancic, J. (2013). Critical race theory: An introduction. Philadelphia: Temple University Press.

DiAngelo, R. (2018). White fragility: Why it's so hard for white people to talk about racism. Boston: Beacon Press.

Dimaggio, P., \& Powell, W. (1983). The iron cage revisited: Institutional isomorphism and collective rationality in organizational fields. American Sociological Review, 48(2), 147160.

DiTomaso, N., Post, C., \& Parks-Yancy, R. (2007). Workforce diversity and inequality: Power, status, and numbers. Annual Review of Sociology, 33(1), 473-501.

DuBois, W. E. B. (1903). The souls of black folk. NY: Bantam.

Edwards, K. (2008). The elusive dream: The power of race in interracial churches. NY: Oxford University Press.

Fanon, F. (1967). Black skin white masks. NY: Grove Press.

Foldy, E., \& Buckley, T. (2014). The color bind: Talking (and not talking) about race at work. NY: Russell Sage.

Frankenberg, R. (1993). The social construction of whiteness: White women, race matters. NY: Routledge.

Ganz, M. (2009). Why David sometimes wins: Leadership, organization, and strategy in the California farm worker movement. NY: Oxford University Press. 
Garner, S. (2007). Whiteness: An introduction. NY: Routledge.

Gillis, D. (2017). Missing pieces report. NY: Catalyst.

Giorgi, S., Bartunek, J., \& King, B. (2017). A Saul Alinsky primer for the 21st century. Research in Organizational Behavior, 37, 125-142.

Hajnal, Z., Lajevardi, N., \& Nielson, L. (2017). Voter identification laws and the suppression of minority votes. Journal of Politics, 79(2), 363-379.

Harding, S. (2004). The feminist standpoint theory reader: Intellectual and political controversies. NY: Routledge.

Harris, G. (2012). Multiple marginality: How the disproportionate assignment of women and minorities to manage diversity programs reinforces and multiplies their marginality. Administration \& Society, 45(7), 775-808.

Hart, S. (2001). Cultural dilemmas of progressive politics: Styles of engagement among grassroots activists. Chicago: University of Chicago Press.

Hartsock, N. (1983). The feminist standpoint: Developing the ground for a specifically feminist historical materialism. NY: Routledge.

Hatch, A. (2007). Critical race theory. Blackwell Encyclopedia of Sociology.

Hebert, J., \& Jenkins, M. (2010). The need for state redistricting reform to rein in partisan gerrymandering. Yale Law \& Policy Review, 29, 543-558.

hooks, b. (1998). Representations of whiteness in the black imagination. In D. Roediger (Ed.), Black on white: Black writers on what it means to be white. NY: Schocken Books.

Hughey, M. (2010). A paradox of participation: Nonwhites in white sororities and fraternities. Social Problems, 57(4), 653-679.

Ignatiev, N., \& Garvey, J. (1996). Race traitor. NY: Routledge.

Jang, S. (2017). Cultural brokerage and creative performance in multicultural teams. Organization Science, 28(6), 993-1009.

Joseph, T., \& Hirshfield, L. (2011). 'Why don't you get somebody new to do it?'Race and cultural taxation in the academy. Ethnic and Racial Studies, 34(1), 121-141.

Kellogg, K. (2011). Challenging operations: Medical reform and resistance in surgery. Chicago: University of Chicago Press.

Kraatz, M. (2009). Leadership as institutional work: A bridge to the other side. Institutional Work, 59-91.

Kwon, H. (2015). Intersectionality in Interaction: Immigrant Youth Doing American from an Outsider-Within Position. Social Problems, 62(4), 623-641.

Lawrence, T., Leca, B., \& Zilber, T. (2013). Institutional work: Current research, new directions and overlooked issues. Organization Studies, 34(8), 1023-1033.

Lawrence, T., \& Suddaby, R. (2006). Institutions and Institutional Work. NY: Sage.

Martin, P., Reynolds, J., \& Keith, S. (2002). Gender bias and feminist consciousness among judges and attorneys: A standpoint theory analysis. Signs, 27(3), 665-701.

McAdam, D., \& Scott, W. R. (2012). Organizations and movements. In J. Ott \& L. Dicke (Eds.), Nature of the Nonprofit Sector (pp. 257-272). Boulder: Westview Press.

McAdam, D., Tarrow, S., \& Tilly, C. (2001). Dynamics of contention. NY: Cambridge University Press.

McCorkel, J., \& Rodriquez, J. (2009). 'Are you an African?' The politics of self-construction in status-based social movements. Social Problems, 56(2), 357-384.

McIntosh, P. (1990). White privilege: Unpacking the invisible knapsack. Independent School, 49(2). 
McKinney, K. (2005). Being white: Stories of race and racism. NY: Routledge.

Meyer, J. W., \& Rowan, B. (1977). Institutionalized organizations: Formal structure as myth and ceremony. American Journal of Sociology, 83(2), 340-363.

Moore, H., Acosta, K., Perry, G., \& Edwards, C. (2010). Splitting the academy: The emotions of intersectionality at work. Sociological Quarterly, 51(2), 179-204.

Morris, A. (1984). The origins of the civil rights movement: Black communities organizing for change. NY: Free Press.

Nepstad, S. (2001). Creating transnational solidarity: The use of narrative in the US-Central America peace movement. Mobilization, 6(1), 21-36.

Oliver, C. (1991). Strategic responses to institutional processes. Academy of Management Review, 16(1), 145-179.

Omi, M., \& Winant, H. (2014). Racial formation in the United States. NY: Routledge.

Ospina, S., \& Foldy, E. (2010). Building bridges from the margins: The work of leadership in social change organizations. The Leadership Quarterly, 21(2), 292-307.

Ostrower, F. (2007). Nonprofit governance in the United States: Findings on performance and accountability from the first national representative study. DC: Urban Institute.

Padilla, A. (1994). Ethnic minority scholars; research, and mentoring: Current and future issues. Educational Researcher, 23(4), 24-27.

Parker, P. (2001). African-American women executives within dominant culture organizations. Management Communication Quarterly, 15(1), 42-82.

Perry, P. (2001). White means never having to say you're ethnic: White youth and the construction of 'cultureless' identities. Journal of Contemporary Ethnography, 30(1), 5691.

Perry, S. (2012). Racial habitus, moral conflict, and white moral hegemony within interracial evangelical organizations. Qualitative Sociology, 35(1), 89-108.

Polletta, F. (2006). It was like a fever: Storytelling in protest and politics. Chicago: University of Chicago Press.

Sampson, R., McAdam, D., MacIndoe, H., \& Weffer-Elizondo, S. (2005). Civil society reconsidered: The durable nature and community structure of collective civic action. American Journal of Sociology, 111(3), 673-714.

Schilt, K. (2006). Just one of the guys? How transmen make gender visible at work. Gender \& Society, 20(4), 465-490.

Sen, R. (2003). Stir it up: Lessons in community organizing and advocacy. SF: Jossey-Bass.

Shapiro, T., Meschede, T., \& Sullivan, L. (2010). The racial wealth gap increases fourfold. Waltham: Institute on Assets and Social Policy.

Slocum, R. (2006). Anti-racist practice and the work of community food organizations. Antipode, 38(2), 327-349.

Smith, D. (1987). The everyday world as problematic: A feminist sociology. Toronoto: University of Toronto Press.

Srivastava, S. (2006). Tears, fears and careers: Anti-racism and emotion in social movement organizations. Canadian Journal of Sociology, 31(1), 55-90.

Staiger, A. (2004). Whiteness as giftedness: Racial formation at an urban high school. Social Problems, 51(2), 161-181.

Stainback, K., Tomaskovic-Devey, D., \& Skaggs, S. (2010). Organizational approaches to inequality: Inertia, relative power, and environments. Annual Review of Sociology, 36(1), 225-247. 
Tarrow, S. (1994). Power in movement: Social movements, collective action, and politics. NY: Cambridge University Press.

Verba, S., Schlozman, K., \& Brady, H. (1995). Voice and equality: Civic voluntarism in American politics. Cambridge: Harvard University Press.

Ward, J. (2008). White normativity: The cultural dimensions of whiteness in a racially diverse LGBT organization. Sociological Perspectives, 51(3), 563-586.

Warren, M. (2010). Fire in the heart: How white activists embrace racial justice. NY: Oxford University Press.

Wingfield, A., \& Alston, R. (2014). Maintaining hierarchies in predominantly white organizations. American Behavioral Scientist, 58(2), 274-287.

Wylie, A. (2013). Why standpoint matters. Science and Other Cultures, 34-56.

Zanoni, P., Janssens, M., Benschop, Y., \& Nkomo, S. (2010). Unpacking diversity, grasping inequality: Rethinking difference through critical perspectives. Organization, 17(1), 9-29.

\section{Endnotes}

${ }^{1}$ The proportion of people of color in leadership positions has been analyzed extensively among organizational boards. In the private sector, 13 percent of Fortune 500 board members are people of color (Gillis, 2017), and in the nonprofit sector, 19 percent of all board members are people of color - that is, even in the nonprofit sector, 81 percent of board members are white (Ostrower, 2007). People of color thus remain substantially underrepresented on organizational boards.

${ }^{2}$ Because the quantitative analysis uses cross-sectional data, causal order cannot be determined nor the impact of exogenous shocks. Consequently, the interpretations of the results avoid using language that implies causality. However, the qualitative analysis provides an initial look at the kinds of causal dynamics that may underlie the relationship.

${ }^{3}$ ELIJAH and all individuals' names are pseudonyms. ELIJAH is not an acronym.

${ }^{4}$ The second author, who is a woman of color, was on ELIJAH's staff as an organizer from August 2009 until August 2010. The other two authors are white men who have extensive experience engaging race-related dynamics within community-based organizations.

${ }^{5}$ The full list of interview question are available upon request.

${ }^{6}$ During the period in which the ethnographic data were collected and the survey was completed, ELIJAH had 11 paid organizers on staff; three of whom were people of color.

${ }^{7}$ The racial/ethnic and gender categorizations of the interviewees are based on self-identification.

${ }^{8}$ Although the exact number of people that Diana mobilized in the mid-2000s is not known, multiple sources confirmed that ELIJAH had a significant presence of Latinxs at the immigration march that Diana referenced. 
Table 1: Descriptive statistics for ELIJAH and the field of predominantly white community organizing organizations

\begin{tabular}{|c|c|c|c|c|c|}
\hline Variable & ELIJAH & Mean & SD & Min & $\operatorname{Max}$ \\
\hline \multicolumn{6}{|l|}{ Internal Focus on Race } \\
\hline Frequency of discussing racial differences & 4.00 & 2.93 & .88 & 1.00 & 4.00 \\
\hline Extent racial differences prolong meetings & 4.00 & 1.73 & 1.05 & 1.00 & 5.00 \\
\hline Extent racial differences complicate meetings & 4.00 & 2.00 & 1.05 & 1.00 & 5.00 \\
\hline \multicolumn{6}{|l|}{ External Focus on Race } \\
\hline Actively organizing people of color & 1.00 & .46 & .50 & .00 & 1.00 \\
\hline Actively addressing race-related issues & 1.00 & .29 & .46 & .00 & 1.00 \\
\hline \multicolumn{6}{|l|}{ Characteristics of the Organization } \\
\hline Organization has at least one organizer of color on staff & 1.00 & .44 & .50 & .00 & 1.00 \\
\hline Proportion of board members who are people of color & .55 & .22 & .17 & .00 & .67 \\
\hline Age of the organization & 12.00 & 11.41 & 7.07 & 2.00 & 30.00 \\
\hline Male director & .00 & .46 & .50 & .00 & 1.00 \\
\hline Age of director & 35.00 & 46.71 & 14.12 & 25.00 & 75.00 \\
\hline Director has an advanced degree & 1.00 & .51 & .51 & .00 & 1.00 \\
\hline Proportion of male board members & .36 & .44 & .16 & .18 & .73 \\
\hline Mean age of board members & 56.82 & 55.04 & 4.41 & 44.38 & 63.46 \\
\hline Proportion of board members with an advanced degree & .91 & .43 & .21 & .09 & .91 \\
\hline Proportion of board members who are clergy & .36 & .23 & .17 & .00 & 67 \\
\hline Proportion of people of color in the organization's county & .28 & .24 & .16 & .05 & 65 \\
\hline
\end{tabular}

Source: 2011 National Study of Community Organizing Organizations.

Note: $\mathrm{N}=41$. 
Table 2: Logistic and ordered logistic regression models estimating whether and the extent to which an organization has an internal and external focus on race

\begin{tabular}{|c|c|c|c|c|c|}
\hline & \multicolumn{3}{|c|}{ Internal Focus on Race } & \multicolumn{2}{|c|}{ External Focus on Race } \\
\hline & $\begin{array}{l}\text { Frequency of } \\
\text { discussing } \\
\text { racial } \\
\text { differences }\end{array}$ & $\begin{array}{c}\text { Extent racial } \\
\text { differences } \\
\text { prolong } \\
\text { meetings }\end{array}$ & $\begin{array}{c}\text { Extent racial } \\
\text { differences } \\
\text { complicate } \\
\text { meetings }\end{array}$ & $\begin{array}{l}\text { Actively } \\
\text { organizes } \\
\text { people of } \\
\text { color }\end{array}$ & $\begin{array}{l}\text { Actively } \\
\text { addresses } \\
\text { race-related } \\
\text { issues }\end{array}$ \\
\hline $\begin{array}{l}\text { Organization has at least one } \\
\text { organizer of color on staff }\end{array}$ & $\begin{array}{l}.257 * \\
(2.058)\end{array}$ & $\begin{array}{l}.380 * * \\
(2.685)\end{array}$ & $\begin{array}{r}.273 \dagger \\
(1.698)\end{array}$ & $\begin{array}{c}.261 * \\
(2.062)\end{array}$ & $\begin{array}{l}.468 * \\
(2.520)\end{array}$ \\
\hline $\begin{array}{l}\text { Proportion of board members } \\
\text { who are people of color }\end{array}$ & $\begin{array}{c}-.245 \\
(-1.312)\end{array}$ & $\begin{array}{c}.335 \\
(1.111)\end{array}$ & $\begin{array}{l}.087 \\
(.455)\end{array}$ & $\begin{array}{c}.053 \\
(.385)\end{array}$ & $\begin{array}{l}.069 \\
(.529)\end{array}$ \\
\hline Age of the organization & $\begin{array}{c}-.159 \\
(-1.374)\end{array}$ & $\begin{array}{c}.145 \\
(1.027)\end{array}$ & $\begin{array}{r}.325 \dagger \\
(1.874)\end{array}$ & $\begin{array}{c}.195 \\
(1.304)\end{array}$ & $\begin{array}{l}-.401 \dagger \\
(-1.955)\end{array}$ \\
\hline Male director & $\begin{array}{c}.287 * \\
(2.082)\end{array}$ & $\begin{array}{c}-.172 \\
(-1.101)\end{array}$ & $\begin{array}{l}-.002 \\
(-.011)\end{array}$ & $\begin{array}{l}-.083 \\
(-.626)\end{array}$ & $\begin{array}{l}-.077 \\
(-.404)\end{array}$ \\
\hline Age of director & $\begin{array}{l}-.117 \\
(-.720)\end{array}$ & $\begin{array}{r}.378 \dagger \\
(1.727)\end{array}$ & $\begin{array}{l}.096 \\
(.623)\end{array}$ & $\begin{array}{c}.147 \\
(.872)\end{array}$ & $\begin{array}{l}.014 \\
(.086)\end{array}$ \\
\hline Director has an advanced degree & $\begin{array}{l}.121 \\
(.865)\end{array}$ & $\begin{array}{c}.190 \\
(.702)\end{array}$ & $\begin{array}{l}-.049 \\
(-.316)\end{array}$ & $\begin{array}{l}.309 * * \\
(2.683)\end{array}$ & $\begin{array}{c}.142 \\
(1.013)\end{array}$ \\
\hline Proportion of male board members & $\begin{array}{l}.123 \\
(.944)\end{array}$ & $\begin{array}{r}-.289 \dagger \\
(-1.672)\end{array}$ & $\begin{array}{l}-.175 \\
(-.830)\end{array}$ & $\begin{array}{c}-.229 \\
(-1.474)\end{array}$ & $\begin{array}{l}-.030 \\
(-.175)\end{array}$ \\
\hline Mean age of board members & $\begin{array}{c}-.251 \\
(-1.561)\end{array}$ & $\begin{array}{l}-.069 \\
(-.601)\end{array}$ & $\begin{array}{l}-.016 \\
(-.110)\end{array}$ & $\begin{array}{l}-.078 \\
(-.677)\end{array}$ & $\begin{array}{l}-.473 * * \\
(-2.764)\end{array}$ \\
\hline $\begin{array}{l}\text { Proportion of board members } \\
\text { with an advanced degree }\end{array}$ & $\begin{array}{c}.285 \\
(1.037)\end{array}$ & $\begin{array}{l}-.067 \\
(-.397)\end{array}$ & $\begin{array}{c}.162 \\
(.912)\end{array}$ & $\begin{array}{c}.081 \\
(.428)\end{array}$ & $\begin{array}{r}.244 \dagger \\
(1.660)\end{array}$ \\
\hline $\begin{array}{l}\text { Proportion of board members } \\
\text { who are clergy }\end{array}$ & $\begin{array}{c}.069 \\
(.310)\end{array}$ & $\begin{array}{l}-.026 \\
(-.141)\end{array}$ & $\begin{array}{l}.037 \\
(.186)\end{array}$ & $\begin{array}{l}.147 \\
(.857)\end{array}$ & $\begin{array}{c}-.447 * \\
(-2.024)\end{array}$ \\
\hline $\begin{array}{l}\text { Proportion of people of color } \\
\text { in the organization's county }\end{array}$ & $\begin{array}{l}.484 * * \\
(3.042)\end{array}$ & $\begin{array}{c}.085 \\
(.301)\end{array}$ & $\begin{array}{c}.243 \\
(1.240)\end{array}$ & $\begin{array}{r}.419 * \\
(2.226)\end{array}$ & $\begin{array}{c}.081 \\
(.605)\end{array}$ \\
\hline
\end{tabular}

Note: $\mathrm{N}=41$. Coefficients are fully standardized; $\mathrm{z}$-statistics in parentheses

${ }^{\mathrm{a}}$ logged values

$\dagger \mathrm{p}<.10 ; * \mathrm{p}<.05 ; * * \mathrm{p}<.01$ 
Table 3: Characteristics of ELIJAH's leaders who participated in the qualitative interviews

\begin{tabular}{lrr}
\hline Characteristic & $\mathrm{N}$ & $\%$ \\
\hline Paid organizers/staff leaders & 10 & $33 \%$ \\
Volunteer leaders & 20 & $67 \%$ \\
White leaders & 24 & $80 \%$ \\
Leaders of color & 6 & $20 \%$ \\
$\quad$ African-American leaders & 3 & $10 \%$ \\
Asian-American leaders & 2 & $7 \%$ \\
Latinx leaders & 1 & $3 \%$ \\
Male leaders & 10 & $33 \%$ \\
Female leaders & 20 & $67 \%$ \\
White male leaders & 8 & $27 \%$ \\
White female leaders & 16 & $53 \%$ \\
Male leaders of color & 2 & $7 \%$ \\
Female leaders of color & 4 & $13 \%$ \\
\hline
\end{tabular}

Note: Total number of ELIJAH's leaders interviewed $=30$. 


\section{Online Appendix A}

Additional details about the National Study of Community Organizing Organizations and the variables and models used in the quantitative analysis

The population for the National Study of Community Organizing Organizations comprised every institution-based community organizing organization in the U.S. that has an office address, at least one paid employee, and institutional members. Institution-based organizing, sometimes referred to as "broad-based," "congregation-based," or "faith-based" organizing, differs from other types of community organizing in that the organizations have institutional members rather than individual members. The population did not include community organizing organizations that have only individual members. Based on these criteria, the study identified 189 active organizations by using databases from every national and regional community organizing network, databases from 14 foundations that fund community organizing, and archived IRS 990 forms. ${ }^{1}$

Because this article focuses on predominantly white organizations, we restrict the sample to organizations for which at least two-thirds of its active institutional members are majority-white organizations. ${ }^{2}$ When the directors provided information about their institutional members, they were asked to indicate the majority race of each institution. 3 If no race constituted a majority for a particular institutional member, the respondent coded the institution as multiracial. Because most voluntary associations tend to be racially homogenous (McPherson et al. 2001), we are confident

\footnotetext{
${ }^{1}$ The organizing networks include the Gamaliel Foundation (gamaliel.org), the Industrial Areas Foundation (industrialareasfoundation.org), National People's Action (npa-us.org), and the PICO National Network (piconetwork.org). Important regional networks include the DART Center (thedartcenter.org) in the Southeast and Midwest, the Ohio Organizing Collaborative (ohorganizing.org), and the Inter-Valley Project in New England (intervalleyproject.org). A smaller number of organizations doing institution-based work also exist independent of the networks.

${ }^{2}$ Additional analyses that shift the percentage threshold of majority-white institutional members for an organization to be coded "predominantly white" do not generate significantly different outcomes.

${ }^{3}$ For each institutional member, the directors were asked to also indicate whether it had been an active member of the organization over the previous 12 months. Institutional members that had not been active in the organization over the previous 12 months were removed from the analysis.
} 
in the directors' ability to accurately report the majority race of their member institutions.

Furthermore, among the member institutions that were coded as majority-white, it is very likely that vast majority of their participants are white (McPherson, Smith-Lovin, and Cook, 2001). ${ }^{4}$

\section{Addressing Racial Inequality Internally}

To measure an organization's internal focus on race (i.e. the extent to which it addresses racial inequality internally as an organization), we use the following variables. Directors were asked to indicate how often their organization explicitly discussed racial differences in their planning meetings over the past 12 months. This ordered categorical variable had five response options (never, rarely, sometimes, often, and always), which we converted to a Likert-type scale ranging from 1 to 5 to construct the variable frequency of discussing racial differences. Directors were also asked to indicate the extent to which racial differences have prolonged and complicated their planning meetings over the past 12 months. For both of these items, we converted the five response options (not at all, minimally, a little, somewhat, and a lot) to a Likert-type scale ranging from 1 to 5 to construct the variables extent racial differences prolong meetings and extent racial differences complicate meetings.

The primary methodological consideration driving the design of these particular survey items was to reduce social desirability bias among the responses. Cognitive pretesting indicated that these items generated substantially less social desirability bias than items such as "Does your organization value racial differences?" and "Does your organization consider racial differences during its planning meetings?". The development of these survey items and their specific wording was based on the authors' ethnographic observations of organizations addressing racial

\footnotetext{
4 The analysis does not include the race of the organization's director because among the predominantly white organizations only four of the directors were people of color.
} 
issues and based on insights drawn from qualitative and experimental research conducted by Bonilla-Silva (2003) and Emerson, Yancey, and Chai (2001).

Although these items do not eliminate social desirability bias, they reduce it. From the perspective of an organizational director, the socially desirable response to these items is not readily apparent. For example, it is unclear whether it is "better" or "worse" for racial differences to prolong and/or complicate an organization's meetings. Consequently, in the absence of a socially desirable response, directors are more likely to recount the actual experience of their organization and respond with that information. We also tested more objective versions of these items, which asked respondents to provide the number of discussions about racial differences and the amount of time meetings were prolonged because of racial differences. However, it was much more difficult for respondents to recall exact numbers and amounts of time than it was to provide relative estimates (e.g., "rarely" or "minimally").

\section{Addressing Racial Inequality Externally}

To measure an organization's external focus on race (i.e. the extent to which it addresses racial inequality in the public sphere), we use the following variables regarding their work over the past 2 years. Directors were asked to indicate how involved their organization has been in organizing people of color. This ordered categorical variable had five response options (not involved, minimally involved, a little involved, somewhat involved, and very involved). We used these responses to construct the binary variable — actively organizes people of color — such that the "very involved" response was coded 1 and the other responses were coded $0 .{ }^{5}$ Directors were also asked to indicate how involved their organization has been in addressing race-related issues.

\footnotetext{
${ }^{5}$ Over 73 percent of the predominantly white organizations indicated being at least "somewhat involved" in organizing people of color, thus the analysis compares the organizations "very involved" in organizing people of color with all of the other organizations.
} 
This ordered categorical variable had the same five response options; we used it to construct the binary variable - actively addresses race-related issues — such that the "somewhat involved" and "very involved" responses were coded 1 and the other responses were coded 0.

\section{Quantitative Models}

The analysis performs ordered logistic regressions for the ordered categorical dependent variables and logistic regressions for the binary dependent variables. Each model estimates the coefficients using maximum likelihood methods and provides the fully standardized coefficients, which measure the change in the log odds of focusing on race associated with a one standard deviation change in the independent variable (Menard, 2011). Because this study surveyed the entire population of institution-based community organizing organizations in the U.S. and received responses from 94 percent of the organizations, a finite population correction factor$\sqrt{(\mathrm{N}-\mathrm{n}) /(\mathrm{N}-1)}$-is applied to each model (Cochran, 1977). The finite population correction factor is based on the 157 organizations (out of 189) that provided complete information on all of the variables used in the analysis.

\section{References}

Bonilla-Silva, E. (2003). Racism without racists: Color-blind racism and racial inequality in contemporary America. Lanham: Rowman \& Littlefield.

Cochran, W. (1977). Sampling techniques. NY: Wiley.

Emerson, M. O., Yancey, G., \& Chai, K. J. (2001). Does race matter in residential segregation? Exploring the preferences of White Americans. American Sociological Review, 66(6), 922.

McPherson, M., Smith-Lovin, L., \& Cook, J. M. (2001). Birds of a feather: Homophily in social networks. Annual Review of Sociology, 27(1), 415-444.

Menard, S. (2011). Standards for Standardized Logistic Regression Coefficients. Social Forces, 89(4), 1409-1428. 